\title{
Leifsonia psychrotolerans sp. nov., a psychrotolerant species of the family Microbacteriaceae from Livingston Island, Antarctica
}

Correspondence
Dirk Wagner
Dirk.Wagner@awi.de

\author{
Lars Ganzert, ${ }^{1}$ Felizitas Bajerski, ${ }^{1}$ Kai Mangelsdorf, ${ }^{2}$ André Lipski ${ }^{3}$ \\ and Dirk Wagner ${ }^{1}$ \\ ${ }^{1}$ Alfred Wegener Institute for Polar and Marine Research, Research Department Potsdam,
Telegrafenberg A45, 14473 Potsdam, Germany
${ }^{2}$ Helmholtz Centre Potsdam GFZ German Research Centre for Geosciences, Section 4.3, Organic
Geochemistry, Telegrafenberg B 423, 14473 Potsdam, Germany
${ }^{3}$ Rheinische Friedrich-Wilhelms-Universität Bonn, Institute of Nutrition and Food Sciences,
Department of Food Microbiology and Hygiene, Meckenheimer Allee 168, 53115 Bonn, Germany
}

A cold-tolerant, yellow-pigmented, Gram-positive, motile, facultatively anaerobic bacterial strain, $\mathrm{LI} 1^{\top}$, was isolated from a moss-covered soil from Livingston Island, Antarctica, near the Bulgarian station St. Kliment Ohridski. Comparative 16S rRNA gene sequence-based phylogenetic analysis placed the strain in a clade with the species Leifsonia kafniensis $\mathrm{KFC}^{-2} 2^{\top}$, Leifsonia pindariensis PON $10^{\top}$ and Leifsonia antarctica SPC- $20^{\top}$, with which it showed sequence similarities of 99.0, 97.9 and $97.9 \%$, respectively. DNA-DNA hybridization revealed a reassociation value of $2.7 \%$ with $L$. kafniensis LMG $24362^{\top}$. The DNA G $+C$ content of strain $\mathrm{LI1}{ }^{\top}$ was $64.5 \mathrm{~mol} \%$. The growth temperature range was -6 to $28{ }^{\circ} \mathrm{C}$, with optimum growth at $16{ }^{\circ} \mathrm{C}$. Growth occurred in $0-5 \% \mathrm{NaCl}$ and at $\mathrm{pH} 4.5-9.5$, with optimum growth in 1-2\% NaCl and at $\mathrm{pH} 5.5-6.5$. The predominant fatty acids were anteiso- $\mathrm{C}_{15: 0}, \mathrm{C}_{18: 0}$ and iso- $\mathrm{C}_{15: 0}$. The polar lipids were phosphatidylglycerol and diphosphatidylglycerol. Physiological and biochemical tests clearly differentiated strain $\mathrm{LI}^{\top}{ }^{\top}$ from $L$. kafniensis. Therefore, a novel cold-tolerant species within the genus Leifsonia is proposed: Leifsonia psychrotolerans sp. nov. (type strain $\mathrm{LI} 1^{\top}=\mathrm{DSM}$ $22824^{\top}=$ NCCB $100313^{\top}$ ).
The genus Leifsonia, originally described by Suzuki et al. (1999) and Evtushenko et al. (2000), belongs to the family Microbacteriaceae, order Actinomycetales and, at the time of writing, comprised 14 species (http://www.bacterio.cict.fr/ 1/leifsonia.html) isolated from different sources such as roots (Evtushenko et al., 2000; Qiu et al., 2007), plants (Davis et al., 1984), distilled water (Leifson, 1962), soil (Dastager et al., 2008, 2009), various cold habitats in Antarctica (Reddy et al., 2003; Pindi et al., 2009) and close to glaciers (Reddy et al., 2008; Pindi et al., 2009). Very recently, Leifsonia ginsengi was reclassified into the novel genus Herbiconiux of the family Microbacteriaceae (Behrendt et al., 2011). L. ginsengi and Herbiconiux solani share chemotaxonomic and phylogenetic features that clearly differentiate them from other members of the genus Leifsonia. The genus Leifsonia is characterized by

Abbreviation: DAB, diaminobutyric acid.

The GenBank/EMBL/DDBJ accession number for the 16S rRNA gene sequence of Leifsonia psychrotolerans $\mathrm{LI}^{\top}{ }^{\top}$ is GQ406810.
Gram-positive, non-spore-forming, irregular rod- or filament-shaped bacteria that possess MK-10 and/or MK11 as major menaquinone and 2,4-diaminobutyric acid (DAB), alanine, glycine and glutamic acid as cell-wall amino acids. The DNA $\mathrm{G}+\mathrm{C}$ contents vary within the genus from 64.0 to $73.4 \mathrm{~mol} \%$. At present, five Leifsonia species [Leifsonia antarctica, Leifsonia aurea (recently reclassified as Rhodoglobus aureus; An et al., 2010), Leifsonia kafniensis, Leifsonia pindariensis and Leifsonia rubra] are psychrotolerant, i.e. able to grow at $4{ }^{\circ} \mathrm{C}$.

In this study, strain $\mathrm{LI}^{\mathrm{T}}{ }^{\mathrm{T}}$, a novel psychrotolerant member of the genus Leifsonia isolated from a cold terrestrial environment in the maritime Antarctic, was characterized and proposed as a representative of a novel species, Leifsonia psychrotolerans sp. nov.

Strain $\mathrm{LI}^{\mathrm{T}}$ was isolated from a moss-layered soil sample collected in 2005 near the Bulgarian Antarctic station St. Kliment Ohridski ( $62^{\circ} 38^{\prime} 29^{\prime \prime}$ S $60^{\circ} 21^{\prime} 53^{\prime \prime} \mathrm{W}$ ), located on Livingston Island, South Shetland Islands, Antarctica. For 
isolation, $5 \mathrm{~g}$ soil was shaken with $10 \mathrm{ml}$ sterile $0.9 \%(\mathrm{w} / \mathrm{v})$ $\mathrm{NaCl}$ solution for $20 \mathrm{~min}$ at 150 r.p.m. Serial dilutions were made with sterile saline solution [0.9\% (w/v) $\mathrm{NaCl}]$, plated $(0.1 \mathrm{ml})$ on a modified synthetic BRII agar (Bunt \& Rovira, 1955) and incubated at $16{ }^{\circ} \mathrm{C}$ for 7-14 days; single colonies were chosen for further purification. The medium used for isolation contained $0.4 \%(\mathrm{w} / \mathrm{v}) \quad \mathrm{K}_{2} \mathrm{HPO}_{4} \cdot 3 \mathrm{H}_{2} \mathrm{O}, 0.5 \%$ $(\mathrm{w} / \mathrm{v})\left(\mathrm{NH}_{4}\right)_{2} \mathrm{HPO}_{4}, 0.005 \%$ (w/v) $\mathrm{MgSO}_{4} \cdot 7 \mathrm{H}_{2} \mathrm{O}, 0.1 \%$ (w/v) $\mathrm{MgCl}_{2} \cdot 6 \mathrm{H}_{2} \mathrm{O}, 0.001 \%$ (w/v) $\mathrm{FeCl}_{3} \cdot 6 \mathrm{H}_{2} \mathrm{O}, 0.1 \%$ (w/v) $\mathrm{CaCl}_{2} \cdot 2 \mathrm{H}_{2} \mathrm{O}, 0.1 \%(\mathrm{w} / \mathrm{v})$ tryptone, $0.1 \%(\mathrm{w} / \mathrm{v})$ yeast extract, $0.5 \%(\mathrm{w} / \mathrm{v})$ glucose, $0.03 \%(\mathrm{w} / \mathrm{v}) \mathrm{Na}_{2} \mathrm{CO}_{3}, 25 \%$ $(\mathrm{v} / \mathrm{v})$ synthetic stone extract and $1.5 \%(\mathrm{w} / \mathrm{v})$ agar in deionized water, $\mathrm{pH}$ 8.0. Synthetic stone extract consisted of $0.0042 \%(\mathrm{w} / \mathrm{v}) \mathrm{NaCl}, 0.0013 \%(\mathrm{w} / \mathrm{v}) \mathrm{AlCl}_{3} \cdot 6 \mathrm{H}_{2} \mathrm{O}$, $0.0005 \%(\mathrm{w} / \mathrm{v}) \quad \mathrm{KNO}_{3}, \quad 0.008 \%(\mathrm{w} / \mathrm{v}) \quad \mathrm{K}_{2} \mathrm{SO}_{4}, \quad 0.0067 \%$ (w/v) $\mathrm{CaSO}_{4} .2 \mathrm{H}_{2} \mathrm{O}, 0.0054 \%$ (w/v) $\mathrm{MgSO}_{4} \cdot 7 \mathrm{H}_{2} \mathrm{O}$ and $0.1 \%(\mathrm{v} / \mathrm{v})$ trace metal mix, $\mathrm{pH} 7.0$, in deionized water. Trace metal mix consisted of $0.286 \%(\mathrm{w} / \mathrm{v}) \mathrm{H}_{3} \mathrm{BO}_{3}, 0.181 \%$ (w/v) $\mathrm{MnCl}_{2} \cdot 4 \mathrm{H}_{2} \mathrm{O}, 0.022 \%$ (w/v) $\mathrm{ZnSO}_{4} \cdot 7 \mathrm{H}_{2} \mathrm{O}, 0.039 \%$ (w/v) $\mathrm{Na}_{2} \mathrm{MoO}_{4} \cdot 2 \mathrm{H}_{2} \mathrm{O}, 0.008 \%(\mathrm{w} / \mathrm{v}) \mathrm{CuSO}_{4} \cdot 5 \mathrm{H}_{2} \mathrm{O}$ and $0.005 \%(\mathrm{w} / \mathrm{v}) \mathrm{Co}\left(\mathrm{NO}_{3}\right)_{2} \cdot 6 \mathrm{H}_{2} \mathrm{O}$ in deionized water. For maintenance and for the determination of morphological, biochemical and physiological characteristics, isolates were grown in half-diluted Luria-Bertani (LB) medium [0.5\% (w/v) tryptone, $0.25 \%(\mathrm{w} / \mathrm{v})$ yeast extract, $0.5 \%$ $(\mathrm{w} / \mathrm{v}) \mathrm{NaCl}$ and, if necessary, $1.5 \%(\mathrm{w} / \mathrm{v})$ agar, $\mathrm{pH}$ 7.2].

Table 1. Differential phenotypic characteristics of strain $\mathrm{LI} 1^{\top}$ and its closest phylogenetic neighbours

Strains: 1, L. psychrotolerans sp. nov. LI1 ${ }^{\mathrm{T}}$; 2, L. kafniensis NCCB $100216^{\mathrm{T}}$ [data from Pindi et al. (2009), except sole carbon source utilization data, which are from this study]; 3, L. pindariensis LMG $24222^{\mathrm{T}}$ (Reddy et al., 2008); 4, L. antarctica NCCB 100227 ${ }^{\mathrm{T}}$ (Pindi et al., 2009); 5, M. viridarii DSM $21772^{\mathrm{T}}$ (Matsumoto et al., 2008); 6, P. gilvus DSM 18319 ${ }^{\mathrm{T}}$ (Lee et al., 2008). +, Positive; -, negative; +/-, weakly positive; ND, no data.

\begin{tabular}{|c|c|c|c|c|c|c|}
\hline Characteristic & 1 & 2 & 3 & 4 & 5 & 6 \\
\hline Motility & + & - & + & - & + & + \\
\hline Range & -6 to 28 & $4-30$ & $4-35$ & $4-25$ & $10-38$ & $4-30$ \\
\hline Optimum & 16 & 22 & 25 & 22 & $15-30$ & 25 \\
\hline \multicolumn{7}{|l|}{ Growth $\mathrm{pH}$ : } \\
\hline $\begin{array}{l}\mathrm{NaCl} \text { growth range } \\
(\%, \mathrm{w} / \mathrm{v})\end{array}$ & $0-5$ & $0-5$ & $0-4$ & $0-5$ & $0-3$ & $0-2$ \\
\hline Anaerobic growth & + & - & - & - & - & - \\
\hline \multicolumn{7}{|l|}{ Hydrolysis of: } \\
\hline Gelatin & - & - & - & + & ND & - \\
\hline Methyl red test & $+1-$ & - & - & - & $\mathrm{ND}$ & $\mathrm{ND}$ \\
\hline \multicolumn{7}{|l|}{ Utilization of: } \\
\hline D-Glucose & + & + & + & + & - & $\mathrm{ND}$ \\
\hline Sucrose & $+1-$ & + & - & - & - & ND \\
\hline D-Xylose & + & + & - & - & - & $\mathrm{ND}$ \\
\hline Maltose & + & + & + & - & + & ND \\
\hline Lactose & + & + & + & - & - & ND \\
\hline Inulin & + & - & + & - & - & ND \\
\hline D-Salicin & + & - & + & - & - & ND \\
\hline Dulcitol & + & - & + & - & - & $\mathrm{ND}$ \\
\hline$m$-Erythritol & + & - & + & + & - & ND \\
\hline DNA G $+C$ content $(\mathrm{mol} \%)$ & 64.5 & $\mathrm{ND}$ & $\mathrm{ND}$ & $\mathrm{ND}$ & 70.0 & 69.8 \\
\hline
\end{tabular}


Growth was tested at temperatures from -6 to $32{ }^{\circ} \mathrm{C}$ by measuring the $\mathrm{OD}_{600}$ over 5-7 days. Tolerances to salt $(\mathrm{NaCl})$ and $\mathrm{pH}$ were tested in media containing $0-7 \%(\mathrm{w} / \mathrm{v})$ $\mathrm{NaCl}$ and at $\mathrm{pH} 4.0-10.0$ (in $0.5 \mathrm{pH}$ unit increments), respectively, over 5-7 days. Anaerobic growth was tested on PYG agar plates $[0.1 \%(\mathrm{w} / \mathrm{v})$ peptone, $0.1 \%(\mathrm{w} / \mathrm{v})$ yeast extract, $0.2 \%(\mathrm{w} / \mathrm{v})$ glucose, $1.5 \%(\mathrm{w} / \mathrm{v})$ agar, $\mathrm{pH} 7.2]$ incubated under an $\mathrm{N}_{2} / \mathrm{CO}_{2}(80: 20, \mathrm{v} / \mathrm{v})$ atmosphere for 14 days. Colony characteristics were determined visually on agar plates between 7 and 14 days of bacterial growth. Cell morphology was examined by light microscopy of cells grown for 2 and 9 days. Gram staining, and flagella and spore detection were carried out by classical procedures as described by Süssmuth et al. (1999). Susceptibility to antibiotics was examined by a filter disc test $(10 \mu \mathrm{g}$ per disc). Acid production from carbohydrates was tested with peptone water $[1 \%(\mathrm{w} / \mathrm{v})$ peptone, $0.5 \%(\mathrm{w} / \mathrm{v}) \mathrm{NaCl}]$ containing different sugar solutions $(1 \%, w / v)$ and bromothymol blue as an indicator according to Hugh \& Leifson (1953). The methyl red test was performed according to Schröder (1991). Catalase activity was determined by bubble production in $10 \%$ hydrogen peroxide solution. Oxidase activity was analysed with $N, N, N^{\prime}, N^{\prime}$-tetramethyl- $p$ phenylenediamine as a redox indicator as described by Kovacs (1956). Hydrolysis of starch and casein and the production of urease, hydrogen sulfide and indole from tryptophan were determined as described by Schröder (1991). Hydrolysis of gelatin was tested by flooding gelatin agar plates with saturated ammonium sulfate solution after incubation. Utilization of various compounds as sole carbon sources was tested using a minimal medium $[0.1 \%(\mathrm{w} / \mathrm{v})$ $\mathrm{NH}_{4} \mathrm{Cl}, 0.1 \%$ (w/v) $\mathrm{K}_{2} \mathrm{HPO}_{4}, 0.05 \%$ (w/v) $\mathrm{KH}_{2} \mathrm{PO}_{4}, 0.02 \%$ (w/v) $\mathrm{MgSO}_{4} .7 \mathrm{H}_{2} \mathrm{O}, 0.001 \%$ (w/v) $\mathrm{CaCl}_{2} .2 \mathrm{H}_{2} \mathrm{O}, 0.2 \%$ $(\mathrm{v} / \mathrm{v})$ trace metal mix, $1.5 \%(\mathrm{w} / \mathrm{v})$ agar] prepared with $0.25 \%$ (w/v) of each carbon compound. Phenotypic characteristics of strain $\mathrm{LI}^{\mathrm{T}}$ are presented in Table 1.

For quantitative analysis of cellular fatty acid composition, cells were grown in half-strength LB medium ( $\mathrm{pH}$ 7.2) at $16{ }^{\circ} \mathrm{C}$ for 3 days. Extraction and analysis of polar lipids and fatty acid methyl esters were conducted according to the protocol of Zink \& Mangelsdorf (2004). Isoprenoid quinones were extracted using the small-scale integrated procedure of Minnikin et al. (1984). Menaquinones were analysed by a Hewlett Packard series 1050 HPLC equipped with an ODS Hypersil column and a diode-array detector. Methanol/isopropyl ether $(9: 2, \mathrm{v} / \mathrm{v})$ was used as mobile phase with a flow rate of $1.0 \mathrm{ml} \mathrm{min}{ }^{-1}$ and a column temperature of $30{ }^{\circ} \mathrm{C}$ ( $\mathrm{Hu}$ et al., 1999). To determine the peptidoglycan structure, cell-wall extracts were prepared according to the method of Schleifer \& Kandler (1972). After derivatization (MacKenzie, 1987), the molar ratio of the amino acids was determined by GC (Groth et al., 1996). Fatty acids of strain $\mathrm{LII}^{\mathrm{T}}$ were identified as follows: anteiso- $\mathrm{C}_{15: 0}(48.6 \%), \mathrm{C}_{18: 0}(17.2 \%)$, iso- $\mathrm{C}_{15: 0}(10.9 \%)$, $\mathrm{C}_{16: 0} \quad(8.8 \%)$, anteiso- $\mathrm{C}_{17: 0}(6.7 \%), \mathrm{C}_{18: 2} \quad(1.8 \%)$, $\mathrm{C}_{18: 1} \omega 9 c(1.7 \%)$, iso- $\mathrm{C}_{16: 0}(1.3 \%), \mathrm{C}_{14: 0}(0.8 \%)$, iso$\mathrm{C}_{17: 0}(0.7 \%), \mathrm{C}_{18: 1} \omega 7 c(0.6 \%), \mathrm{C}_{20: 0}(0.5 \%)$ and $\mathrm{C}_{15: 0}$
$(0.4 \%)$. This differed from the fatty acid composition of the closest relative, Leifsonia kafniensis, when grown under identical growth conditions (Table 2). The polar lipids of strain LI1 ${ }^{\mathrm{T}}$ were phosphatidylglycerol and diphosphatidylglycerol. Menaquinones were MK-10 (56\%) and MK-11 $(44 \%)$. For strain $\mathrm{LI}^{\mathrm{T}}$, peptidoglycan structure analysis revealed type $\mathrm{B} 2 \gamma$ with a D-Glu-D-DAB interpeptide bridge, type B7 according to the DSMZ (2001). Amino acid analyses of cell walls showed the presence of $\mathrm{DAB}$, glycine, alanine and glutamic acid with a DAB: Gly: Ala: Glu ratio of $1.5: 0.9: 0.4: 1.0$.

DNA-DNA hybridization was performed by isolating DNA from strain $\mathrm{LI}^{\mathrm{T}}$ and L. kafniensis LMG $24362^{\mathrm{T}}$ using a French pressure cell (Thermo Spectronic) for the disruption of cells. DNA was purified by chromatography on hydroxyapatite as described by Cashion et al. (1977). DNA-DNA hybridization was carried out as described by De Ley et al. (1970) under consideration of the modifications described by Huß et al. (1983) using a model Cary 100 Bio UV/VIS spectrophotometer equipped with a Peltier-thermostatted $6 \times 6$ multicell changer and a temperature controller with in situ temperature probe (Varian). Reassociation experiments were performed in $2 \times$ SSC plus $10 \%$ formamide at $69^{\circ} \mathrm{C}$. Determination of DNA G $+\mathrm{C}$ content was done by HPLC according to the method of Mesbah et al. (1989). DNA isolation from strain $\mathrm{LI}^{\mathrm{T}}$ was conducted using the Microbial DNA isolation kit (MoBio Laboratories). For 16S rRNA gene amplification, general bacterial primers $8 \mathrm{~F}$ (Ravenschlag et al., 1999) and 1492R (Dojka et al., 1998) were used. Sequencing (GATC Biotech, Konstanz, Germany) resulted in a 1357 bp gene

Table 2. Fatty acid compositions (\%) of strain $\mathrm{LI}^{\top}$ and L. kafniensis NCCB $100216^{\top}$ under identical growth conditions.

- , Not detected.

\begin{tabular}{|lcc|}
\hline Fatty acids & LI1 $^{\text {T }}$ & L. kafniensis \\
\hline $\mathrm{C}_{14: 0}$ & - & 0.1 \\
iso- $\mathrm{C}_{14: 0}$ & - & 0.1 \\
$\mathrm{C}_{15: 0}$ & 0.4 & 0.1 \\
iso- $_{15: 0}$ & 10.9 & 0.5 \\
anteiso- $_{15: 0}$ & 48.6 & 65.1 \\
$\mathrm{C}_{16: 0}$ & 8.8 & 1.7 \\
iso- $_{16: 0}$ & 1.3 & 4.1 \\
$\mathrm{C}_{16: 1} \omega 7 c$ & - & 0.1 \\
$\mathrm{C}_{16: 1} \omega 9 c$ & - & 0.1 \\
$\mathrm{C}_{17: 0}$ & - & 0.1 \\
iso- $\mathrm{C}_{17: 0}$ & 0.7 & 0.2 \\
anteiso-C & 6.7 & 27.1 \\
$\mathrm{C}_{18: 0}: 0$ & 17.2 & 0.4 \\
$\mathrm{C}_{18: 1} \omega 7 c$ & 0.6 & - \\
$\mathrm{C}_{18: 1} \omega 9 c$ & 1.7 & 0.2 \\
$\mathrm{C}_{18: 2}$ & 1.8 & - \\
anteiso- & - & 0.1 \\
$\mathrm{C}_{20: 0}: 0$ & 0.5 & - \\
\hline
\end{tabular}




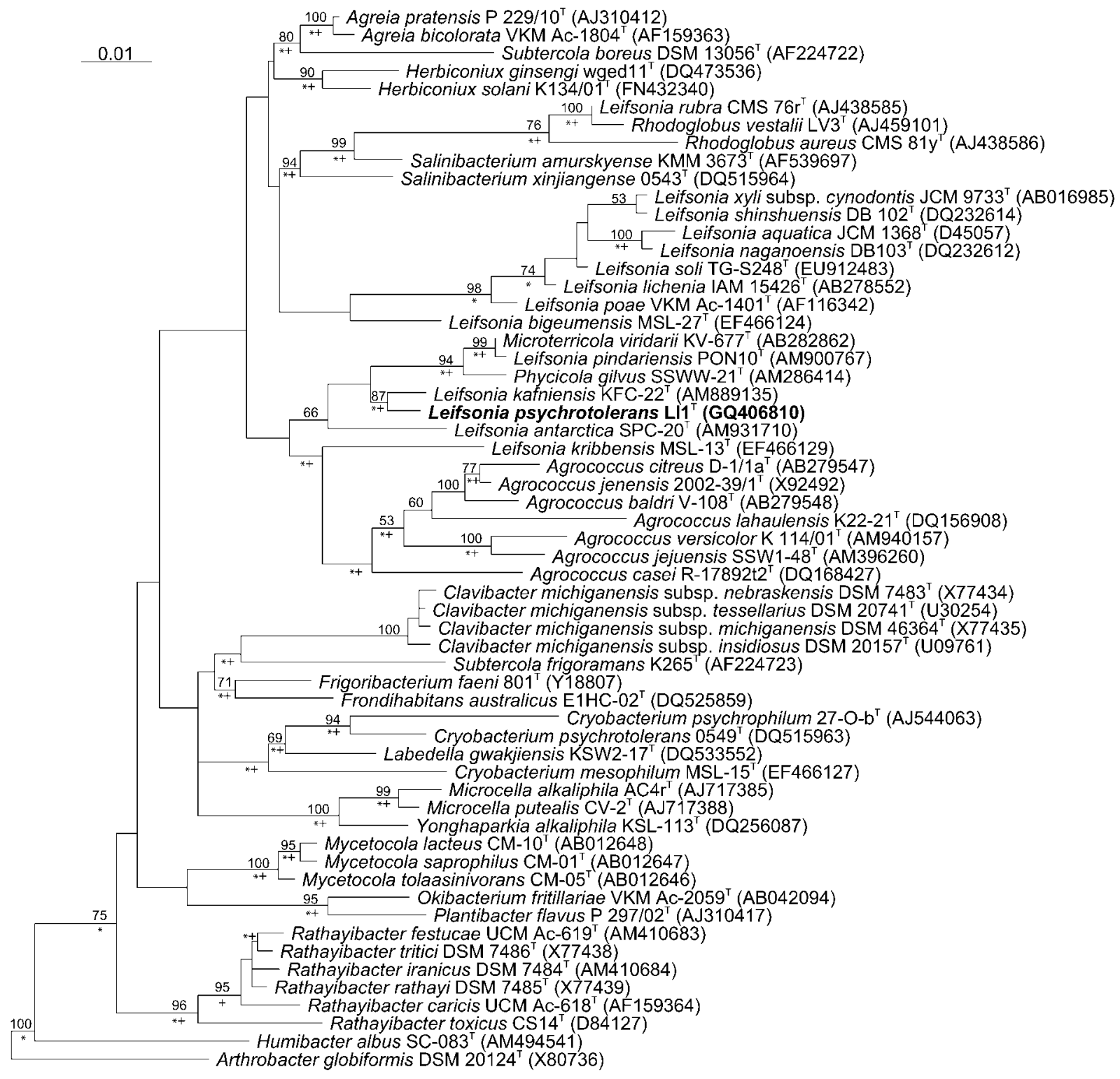

Fig. 1. Neighbour-joining tree of Microbacteriaceae species showing the phylogenetic position of the novel isolate $\mathrm{LI} 1^{\top}$ within this genus. *, Branches that were also found in maximum-parsimony trees (Fitch, 1971); +, branches that were also found in maximum-likelihood trees (Felsenstein, 1981). Numbers at nodes indicate bootstrap-support values (Felsenstein, 1985) based on a neighbour-joining analysis of 1000 replications; only values $\geqslant 50 \%$ are shown. Bar, 0.01 substitutions per nucleotide position.

product for $\mathrm{LI} 1^{\mathrm{T}}$. Alignments were done with closely related sequences obtained from GenBank using the integrated SINA alignment tool from the ARB-SILVA website (Pruesse et al., 2007) and were checked manually. The ARB program (Ludwig et al., 2004) was used for calculation of evolutionary distances. 16S rRNA gene sequence analysis placed the isolate in a clade with $L$. kafniensis $\mathrm{KFC}-22^{\mathrm{T}}$, L. pindariensis $\mathrm{PON}^{\mathrm{T}} 0^{\mathrm{T}}$ and $L$. antarctica $\mathrm{SPC}-20^{\mathrm{T}}$, with sequence similarities of 99.0, 97.9 and $97.9 \%$, respectively. Strain $\mathrm{LI}^{\mathrm{T}}{ }^{\mathrm{s}}$ shared the highest $16 \mathrm{~S}$ rRNA gene sequence similarity with the type strain of $L$. kafniensis $(99.0 \%)$.
Nonetheless, DNA-DNA hybridization between the two strains showed a relatedness of only $2.7 \%$ (repeat value $2.6 \%$ ), indicating that strain $\mathrm{LI}^{\mathrm{T}}$ represents a novel species. For phylogenetic tree construction, the neighbour-joining method (Saitou \& Nei, 1987; Fig. 1), with the correction of Jukes \& Cantor (1969) and a termini filter that is implemented in the ARB program, was used. To evaluate tree topologies, bootstrap analysis with 1000 replications was performed (Felsenstein, 1985). Additionally, maximum-parsimony (Fitch, 1971) and maximum-likelihood (Felsenstein, 1981) trees were calculated to support the 
branching of the neighbour-joining algorithm. The compared trees showed some differences in the position of single species, but the overall topology was similar among the different trees (data not shown). Phylogenetic analyses revealed the polyphyletic structure of the genus Leifsonia, where the species cluster in three clades (in accordance with Pindi et al., 2009). Although strain $\mathrm{LI}^{\mathrm{T}}$, L. antarctica, L. kafniensis and L. pindariensis form a phylogenetic cluster with two other genera, i.e. Microterricola (Matsumoto et al., 2008) and Phycicola (Lee et al., 2008), they share specific biochemical properties that are typical for the genus Leifsonia, such as MK-10 and/or MK-11 as major menaquinones and 2,4-DAB, alanine, glycine and glutamic acid as cell-wall amino acids. On the other hand, Phycicola gilvus is characterized by the formation of budding-like structures, the presence of phosphatidylcholine and phosphatidylinositol in the polar lipid fraction and a rod-coccus cycle. Microterricola viridarii exhibits very similar biochemical features to those of the genus Leifsonia, but the major menaquinone is MK-12.

Therefore, based on morphological, physiological and biochemical characteristics, strain $\mathrm{LII}^{\mathrm{T}}$ can be clearly differentiated from its most closely related neighbours (see Table 1) and is proposed as a representative of a novel species of the genus Leifsonia.

\section{Description of Leifsonia psychrotolerans sp. nov.}

Leifsonia psychrotolerans (psy.chro.to'le.rans. Gr. adj. psychros cold; L. part. adj. tolerans tolerating; N.L. part. adj. psychrotolerans cold-tolerating).

Cells are Gram-positive, motile, non-spore-forming short rods $(0.3 \times 0.9 \mu \mathrm{m})$. Colonies are circular, convex, translucent and yellow in colour. Grows at -6 to $28{ }^{\circ} \mathrm{C}$ (optimum $16{ }^{\circ} \mathrm{C}$ ) and at $\mathrm{pH}$ 4.5-9.5 (optimum $\mathrm{pH} 5.5-$ 6.5). Tolerates up to $5 \% \mathrm{NaCl}$ (optimum $1-2 \% \mathrm{NaCl}$ ). Positive for catalase, $\mathrm{H}_{2} \mathrm{~S}$ production and methyl red test (weak), but negative for oxidase, urease and indole production. Hydrolyses starch (weak), but not casein, Tween 20 or gelatin. Grows on nutrient, LB and tryptic soy agar media, but not on mineral medium. Unlike other members of the genus Leifsonia, can grow anaerobically with glucose as carbon source. Produces acid from D-galactose, D-glucose, L-rhamnose, salicin (weak) and sucrose (weak), but not from lactose, maltose, D-mannitol, adonitol, L-arabinose, dulcitol, myo-inositol, D-sorbitol, trehalose or D-xylose. Can utilize L-arabitol (weak), cellobiose, dulcitol (weak), $m$-erythritol, D-fructose (weak), L-fucose, D-glucose, myo-inositol, inulin, lactose, maltose, D-mannose, melezitose, L-rhamnose, D-ribose, sucrose (weak), D-salicin, sorbitol, D-xylose, acetate, L-asparagine, glycerol, glycogen (weak), pyruvate and succinate, but not adonitol, formate, glycine, lactate, melibiose, raffinose or trehalose as sole carbon source. Sensitive to penicillin, neomycin, streptomycin, oxytetracycline, novobiocin, rifampicin and kanamycin. Resistant to ampicillin and erythromycin. Major menaquinone is
MK-10. Major fatty acid ( $>20 \%$ of total composition) is anteiso- $\mathrm{C}_{15: 0}$.

The type strain is $\mathrm{LIl}^{\mathrm{T}}\left(=\mathrm{DSM} 22824^{\mathrm{T}}=\mathrm{NCCB} 100313^{\mathrm{T}}\right)$, isolated from moss-covered soil from Livingston Island, South Shetland Islands, Antarctica. The genomic DNA $\mathrm{G}+\mathrm{C}$ content of $\mathrm{LII}^{\mathrm{T}}$ is $64.5 \mathrm{~mol} \%$.

\section{Acknowledgements}

Our special gratitude goes to all colleagues on the Bulgarian base St. Kliment Ohridski for supporting fieldwork and logistics, particularly Christo Pimpirev (Bulgarian Antarctic Institute) for his leadership of the expedition Livingston 2005. Furthermore, we wish to thank Hans Hubberten and Georg Schwamborn (Alfred Wegener Institute for Polar and Marine Research) for successful and enjoyable field work. This work was supported by the Deutsche Forschungsgemeinschaft (DFG) in the framework of the priority program Antarctic Research with Comparative Investigations in Arctic Ice Areas, by grants to D. W. (WA 1554/4) and A. L. (LI 1624/2).

\section{References}

An, S. Y., Xiao, T. \& Yokota, A. (2010). Reclassification of Leifsonia aurea to the genus Rhodoglobus as Rhodoglobus aureus comb. nov., and emended description of Rhodoglobus vestalii Sheridan et al. 2003. J Gen Appl Microbiol 56, 53-55.

Behrendt, U., Schumann, P., Hamada, M., Suzuki, K., Spröer, C. \& Ulrich, A. (2011). Reclassification of Leifsonia ginsengi (Qiu et al. 2007) as Herbiconiux ginsengi gen. nov., comb. nov. and description of Herbiconiux solani sp. nov., an actinobacterium associated with the phyllosphere of Solanum tuberosum L. Int J Syst Evol Microbiol 61, 1039-1047.

Bunt, J. S. \& Rovira, A. D. (1955). Microbiological studies of some subantarctic soils. J Soil Sci 6, 119-128.

Cashion, P., Holder-Franklin, M. A., McCully, J. \& Franklin, M. (1977). A rapid method for the base ratio determination of bacterial DNA. Anal Biochem 81, 461-466.

Dastager, S. G., Lee, J.-C., Ju, Y.-J., Park, D.-J. \& Kim, C.-J. (2008). Leifsonia bigeumensis sp. nov., isolated from soil on Bigeum Island, Korea. Int J Syst Evol Microbiol 58, 1935-1938.

Dastager, S. G., Lee, J.-C., Ju, Y.-J., Park, D.-J. \& Kim, C.-J. (2009). Leifsonia kribbensis sp. nov., isolated from soil. Int J Syst Evol Microbiol 59, 18-21.

Davis, M. J., Gillaspie, A. G., Jr, Vidaver, A. K. \& Harris, R. W. (1984). Clavibacter: a new genus containing some phytopathogenic coryneform bacteria, including Clavibacter xyli subsp. xyli sp. nov., subsp. nov. and Clavibacter xyli subsp. cynodontis subsp. nov., pathogens that cause ratoon stunting disease of sugarcane and bermudagrass stunting disease. Int J Syst Bacteriol 34, 107-117.

De Ley, J., Cattoir, H. \& Reynaerts, A. (1970). The quantitative measurement of DNA hybridization from renaturation rates. Eur $J$ Biochem 12, 133-142.

Dojka, M. A., Hugenholtz, P., Haack, S. K. \& Pace, N. R. (1998). Microbial diversity in a hydrocarbon- and chlorinated-solventcontaminated aquifer undergoing intrinsic bioremediation. Appl Environ Microbiol 64, 3869-3877.

DSMZ (2001). Catalogue of Strains, 7th edn. Braunschweig: DSMZ. http://www.dsmz.de/microorganisms/main.php?content_id=35

Evtushenko, L. I., Dorofeeva, L. V., Subbotin, S. A., Cole, J. R. \& Tiedje, J. M. (2000). Leifsonia poae gen. nov., sp. nov., isolated 
from nematode galls on Poa annua, and reclassification of 'Corynebacterium aquaticum' Leifson 1962 as Leifsonia aquatica (ex Leifson 1962) gen. nov., nom. rev., comb. nov. and Clavibacter xyli Davis et al. 1984 with two subspecies as Leifsonia xyli (Davis et al. 1984) gen. nov., comb. nov. Int J Syst Evol Microbiol 50, 371-380.

Felsenstein, J. (1981). Evolutionary trees from DNA sequences: a maximum likelihood approach. J Mol Evol 17, 368-376.

Felsenstein, J. (1985). Confidence limits on phylogenies: an approach using the bootstrap. Evolution 39, 783-791.

Fitch, W. M. (1971). Toward defining the course of evolution: minimum change for a specific tree topology. Syst Zool 20, 406-416.

Groth, I., Schumann, P., Weiss, N., Martin, K. \& Rainey, F. A. (1996). Agrococcus jenensis gen. nov., sp. nov., a new genus of actinomycetes with diaminobutyric acid in the cell wall. Int J Syst Bacteriol 46, 234-239.

Hu, H.-Y., Fujie, K. \& Urano, K. (1999). Development of a novel solid phase extraction method for the analysis of bacterial quinones in activated sludge with a higher reliability. J Biosci Bioeng 87, 378-382.

Hugh, R. \& Leifson, E. (1953). The taxonomic significance of fermentative versus oxidative metabolism of carbohydrates by various gram negative bacteria. J Bacteriol 66, 24-26.

Huß, V. A. R., Festl, H. \& Schleifer, K. H. (1983). Studies on the spectrophotometric determination of DNA hybridization from renaturation rates. Syst Appl Microbiol 4, 184-192.

Jukes, T. H. \& Cantor, C. R. (1969). Evolution of protein molecules. In Mammalian Protein Metabolism, vol. 3, pp. 21-132. Edited by H. N. Munro. New York: Academic Press.

Kovacs, N. (1956). Identification of Pseudomonas pyocyanea by the oxidase reaction. Nature 178, 703.

Lee, D. W., Lee, J. M., Seo, J. P., Schumann, P., Kim, S. J. \& Lee, S. D. (2008). Phycicola gilvus gen. nov., sp. nov., an actinobacterium isolated from living seaweed. Int J Syst Evol Microbiol 58, 1318-1323.

Leifson, E. (1962). The bacterial flora of distilled and stored water. III. New species of the genera Corynebacterium, Flavobacterium, Spirillum and Pseudomonas. Int Bull Bacteriol Nomencl Taxon 12, 161-170.

Ludwig, W., Strunk, O., Westram, R., Richter, L., Meier, H., Yadhukumar, Buchner, A., Lai, T., Steppi, S. \& other authors (2004). ARB: a software environment for sequence data. Nucleic Acids Res 32, 1363-1371.

MacKenzie, S. L. (1987). Gas chromatographic analysis of amino acids as the $N$-heptafluorobutyryl isobutyl esters. J Assoc Off Anal Chem 70, 151-160.

Matsumoto, A., Yamada, M., Ōmura, S. \& Takahashi, Y. (2008). Microterricola viridarii gen. nov., sp. nov., a new member of the family Microbacteriaceae. Int J Syst Evol Microbiol 58, 1019-1023.

Mesbah, M., Premachandran, U. \& Whitman, W. (1989). Precise measurement of the $\mathrm{G}+\mathrm{C}$ content of deoxyribonucleic acid by high-performance liquid chromatography. Int J Syst Bacteriol 39, 159-167.

Minnikin, D. E., O’Donnell, A. G., Goodfellow, M., Alderson, G., Athalye, M., Schaal, A. \& Parlett, J. H. (1984). An integrated procedure for the extraction of bacterial isoprenoid quinones and polar lipids. J Microbiol Methods 2, 233-241.

Pindi, P. K., Kishore, K. H., Reddy, G. S. N. \& Shivaji, S. (2009). Description of Leifsonia kafniensis sp. nov. and Leifsonia antarctica sp. nov. Int J Syst Evol Microbiol 59, 1348-1352.

Pruesse, E., Quast, C., Knittel, K., Fuchs, B. M., Ludwig, W., Peplies, J. \& Glöckner, F. O. (2007). SILVA: a comprehensive online resource for quality checked and aligned ribosomal RNA sequence data compatible with ARB. Nucleic Acids Res 35, 7188-7196.

Qiu, F., Huang, Y., Sun, L., Zhang, X., Liu, Z. \& Song, W. (2007). Leifsonia ginsengi sp. nov., isolated from ginseng root. Int J Syst Evol Microbiol 57, 405-408.

Ravenschlag, K., Sahm, K., Pernthaler, J. \& Amann, R. (1999). High bacterial diversity in permanently cold marine sediments. Appl Environ Microbiol 65, 3982-3989.

Reddy, G. S. N., Prakash, J. S. S., Srinivas, R., Matsumoto, G. I. \& Shivaji, S. (2003). Leifsonia rubra sp. nov. and Leifsonia aurea sp. nov., psychrophiles from a pond in Antarctica. Int $J$ Syst Evol Microbiol 53, 977-984.

Reddy, G. S. N., Prabagaran, S. R. \& Shivaji, S. (2008). Leifsonia pindariensis sp. nov., isolated from the Pindari glacier of the Indian Himalayas, and emended description of the genus Leifsonia. Int J Syst Evol Microbiol 58, 2229-2234.

Saitou, N. \& Nei, M. (1987). The neighbor-joining method: a new method for reconstructing phylogenetic trees. Mol Biol Evol 4, 406-425.

Schleifer, K. H. \& Kandler, O. (1972). Peptidoglycan types of bacterial cell walls and their taxonomic implications. Bacteriol Rev 36, 407-477.

Schröder, H. (1991). Mikrobiologisches Praktikum, 5th edn. Berlin: Volk und Wissen Verlag.

Süssmuth, R., Eberspächer, J., Haag, R. \& Springer, W. (1999). Mikrobiologisch-Biochemisches Praktikum, 2nd edn. Stuttgart: Georg Thieme Verlag.

Suzuki, K. I., Suzuki, M., Sasaki, J., Park, Y. H. \& Komagata, K. K. (1999). Leifsonia gen. nov., a genus for 2,4-diaminobutyric acidcontaining actinomycetes to accommodate "Corynebacterium aquaticum" Leifson 1962 and Clavibacter xyli subsp. cynodontis Davis et al. 1984. J Gen Appl Microbiol 45, 253-262.

Zink, K.-G. \& Mangelsdorf, K. (2004). Efficient and rapid method for extraction of intact phospholipids from sediments combined with molecular structure elucidation using LC-ESI-MS-MS analysis. Anal Bioanal Chem 380, 798-812. 